POLITICS AND INTERNATIONAL RELATIONS

\title{
Structuring Public Opinion on Foreign Policy Issues: The Case of Brazil
}

\author{
Maria Hermínia Tavares de Almeida¹, Ivan Filipe Fernandes ${ }^{2}$ and Feliciano de Sá \\ Guimarães $^{1}$ \\ 1 University of São Paulo, BR \\ 2 Federal University of $\mathrm{ABC}, \mathrm{BR}$ \\ Corresponding author: Feliciano de Sá Guimarães (felicianosa@usp.br)
}

This article analyzes the structure and the stability of Brazilian public attitudes toward foreign policy issues. It argues that Brazilian attitudes on foreign affairs are more structured and stable than has previously been believed. It asserts that deep and historical beliefs about Brazil's role in international affairs, such as pacifism and protagonism, are responsible for creating reasonably consistent and stable public attitudes toward specific foreign policy preferences. The argument builds on the model proposed by Jon Hurwitz and Mark Peffley (1987) in their study on the coherence of US public opinion on foreign policy issues. The article uses survey data from two national samples undertaken in 2014 and 2019 (about 1,800 respondents each). The samples are part of the "Brazil, the Americas and the World" project, which conveys information about Brazilian public opinion on foreign policy issues.

Este artigo analisa a estrutura e a estabilidade das atitudes da opinião pública brasileira em relação às questões de política externa. Argumentamos que as atitudes brasileiras em relação às relações exteriores são mais estruturadas e estáveis do que se pensava. Sustentamos que crenças profundas e históricas sobre o papel do Brasil nos assuntos internacionais, como pacifismo e protagonismo, são responsáveis por criar atitudes públicas razoavelmente consistentes e estáveis em relação a preferências de política externa. Construímos nosso argumento com base no modelo proposto por Hurwitz e Peffley (1987) em seu estudo sobre a coerência da opinião pública nos Estados Unidos em questões de política externa. Usamos dados de pesquisas de duas amostras nacionais realizadas em 2014 e 2019 (cerca de 1.800 entrevistados cada). As amostras fazem parte do projeto O Brasil, As Américas e o Mundo, que levanta informações sobre a opinião pública brasileira em questões de política externa.

Many scholars have assumed that the public attitudes toward foreign policy issues in Brazil are random, disorganized, and unconstrained, if they exist at all (Albuquerque 1998; Souza 2008). The same can be said about other countries in Latin American (Schiavon and Flores 2010). In this article, we argue that, contrary to this widespread notion, Brazilian attitudes toward foreign policy issues are more structured and stable than previously thought.

We sustain that attitudes toward specific foreign policy actions, such as South-South diplomacy or the US-Brazil relationship, are related to preferences for specific postures (abstract beliefs regarding appropriate general governmental strategies) that, in turn, are connected to more rooted and historical beliefs about Brazil's role in international affairs, such as pacifism and protagonism.

This hierarchical belief system is responsible for creating a reasonably consistent and stable public opinion on foreign policy issues. To sustain the hypothesis, we use two nationally representative samples undertaken in 2014 and 2019 (1,815 for both samples) carried out by the Americas and the World Project. ${ }^{1}$

\footnotetext{
${ }^{1}$ For information about the sample, see Appendix 1, item 01.
} 
We adopt the model proposed by Hurwitz and Peffley (1987) for the study of the structure of US public opinion on foreign policy to analyze the structure of Brazilian attitudes. The hierarchical model of foreign policy belief systems stipulates that attitudes toward specific foreign policies are constrained by more general foreign policy beliefs (e.g., postures and images of other nations), which in turn are constrained by even more general core values (e.g., ethnocentrism, morality of war).

Thus, we design a threefold hierarchical model to capture how the Brazilian public structures attitudes toward foreign policy issues. The goal is to assess whether deeply rooted perceptions about Brazil's role in international affairs, such as pacifism and protagonism, constrain postures regarding appropriate government involvement in foreign affairs. These postures refer to public support for multilateralism, regionalism, and Americanism. In turn, we analyze whether these postures constrain more specific foreign policy actions, such as South-South diplomacy, the US-Brazil bilateral relationship, relationships between Brazil and Latin American neighbors, and the strengthening of multilateral institutions.

\section{From Incoherence to Structure}

Discussion of the nature of public opinion on foreign policy has a long tradition, especially in the United States. The first studies in the 1960s and 1970s suggested that the American public was uninterested and misinformed about world affairs, and therefore could have only incoherent and volatile perceptions of foreign policy. According to this interpretation, called the Almond-Lippmann consensus, the public's stable and coherent opinions about politics relied on high levels of information and interest, and this was only possible when the issue at stake was close enough to the individuals' daily experience, which was rarely the case for international affairs (Holsti 1992).

Scholars contested this position in the early 1980s and offered new evidence to the contrary. Shapiro and Page were among the first to present direct empirical evidence of the public's capabilities to comprehend foreign policy issues and to show that shifts in their understanding occurred due to international environmental changes, such as wars, and not to something closely related to their daily routines (Page and Shapiro 1982, 1992; Shapiro and Page 1988).

However, it was one particular study that has changed how the literature engaged the issues of stability and coherence. In 1987, Hurwitz and Peffley published the article "How Are Foreign Policy Attitudes Structured?" whose main goal was to assess whether US public opinion was coherent and stable, therefore challenging the old consensus of volatility and instability. Using a hierarchical model of beliefs and postures, Hurwitz and Peffley found consistent evidence that the public had a better understanding of foreign affairs than previously thought and that their attitudes were coherent and stable.

In the early 1990s, Holsti (1992) argued that challenging the consensus would require more than just one study and that the debate should include, among other factors, cross-national studies and better accumulation of surveys. Eventually, a wave of researchers reassessed the ever-growing survey data and concluded that the public had discernible patterns, stability, and coherence in opinions about international issues, despite having limited information (Maggiotto and Wittkopf 1981; Wittkopf 1990; Popkin 1993; Holsti 2004).

By the early 2000s, a new consensus had emerged. Reviewing the literature on public opinion and the American foreign policy, Aldrich et al. (2006) pointed out that new consensus revolved around two key issues. First, citizens do have a significant information deficit about world affairs as compared to leaders, putting them at a comparable disadvantage. Second, they compensate for this deficit following heuristic clues provided by leaders, which enables them to make reasoned judgments from limited amounts of information.

In this vein, Baum and Potter $(2008,2015)$ argue that attitudes toward foreign policy issues emerge from a complex process whereby governmental officials, high-level bureaucrats, public intellectuals, and the mass media exert influence on the public's perceptions. Therefore, they provide cognitive shortcuts, allowing the public to circumvent its information liabilities (Sniderman, Brody, and Tetlock 1991; Popkin 1993).

Furthermore, some studies show that US citizens base their opinions about foreign policy issues on abstract principles, such as preferences for internationalism or isolationism, as well as on images of specific foreign nations (Herrmann, Tetlock, and Visser 1999; Hurwitz and Peffley 1987; Peffley and Hurwitz 1992; Wittkopf 1990). Baumgartner, Francis, and Morris (2008) explore how religious beliefs sometimes contribute to the formation of foreign policy beliefs. Gadarian (2010) and Baum and Groeling (2010) show how citizens who hold significantly different foreign policy views can be affected by emotionally powerful environments, such as wars, which change their deep-rooted values and more observable preferences about foreign affairs. 
The same can be said of other publics in Western Europe, albeit with fewer evidence and studies than in the United States. The study of Gravelle, Reifler, and Scotto (2017) comparing the structure of foreign policy attitudes in France, Germany, the United Kingdom, and the United States using the Hurwitz and Peffley model finds a standard set of core constructs structuring both American and European attitudes. Nevertheless, they argue that the debate still relied excessively on the American public opinion, or the comparison between the United States and other single countries (Bjereld and Ekengren 1999; Hurwitz, Peffley, and Seligson 1993).

In sum, research is being continually refined on how the public formulates beliefs and opinions on foreign policy issues in the United States and Western Europe. The literature has shown that these publics have consistent and stable perceptions, and that understanding the transmission processes between political leaders and the public is a promising and burgeoning research agenda, one that is currently moving away from the debate of stability versus volatility to focus on the solution of this transmission puzzle (Aldrich et al. 2006; Baum and Potter 2008).

The growing consensus on stability and structure seen in the United States and Europe did not happen in Latin America. Only a handful of studies have addressed how the domestic public perceives foreign affairs in the region (Souza 2008; Almeida 2016; Onuki, Mourón, and Urdinez 2016; Mourón, Urdinez, and Onuki 2016; Reynolds et al. 2017; Guimarães, Fernandes, and Maldonaldo 2020; Castillo, Maldonado, and Shiavon 2015). Similar to the European case, these studies are predominantly focused on narrow and specific issues, such as immigration in Mexico (Schiavon 2010), diplomatic relations between Brazil and Argentina (Lustig and Olego 2016), defense in Argentina (Fraga and Asa 2010), or regional leadership in Brazil (Guimarães, Fernandes, and Maldonaldo 2020).

The exception is the cross-country comparison made by Castillo, Maldonado, and Shiavon (2015). Using data from the Americas and the World Project, applied in 2010, they have shown that there is coherence in the opinions of citizens from five Latin American countries (Brazil, Colombia, Ecuador, Mexico, and Peru) and that political ideology of individuals accounts for such stability. They argue that the differences of opinion among Latin Americans concerning foreign issues cannot be explained by amount of knowledge but rather by a set of values reflected in individual political ideology, as measured on a left-right spectrum.

In Brazil, the debate in the 1990s and 2000s created a consensus that the public did not care about and had no interest in international relations. Also, the public's exposure to information on international affairs was minimal, which impaired their ability to follow and comprehend complex international problems. Analyzing restrictive samples of the elite foreign policy community, both Albuquerque (1998) and Souza (2008) argued that academics and pundits in Brazil should focus on how the foreign policy elite perceived global problems rather than the general public, seen as misinformed and disinterested. For them, only elitelevel analyses could render enough evidence to understand the role of perceptions and attitudes in foreign affairs policymaking. ${ }^{2}$

We disagree with the view that the Brazilian public has volatile and incoherent attitudes toward foreign affairs for two main reasons. First, these studies build their claims by merely analyzing survey results; they did not use specific statistical models to analyze structure and stability. Second, they simply disregarded the well-established notion in the literature that the elite and the public have more in common in terms of foreign affairs attitudes than has been previously believed (Baum and Potter 2008, 2015).

By exploring data from two nationally representative Brazilian samples in 2014 and 2019 from the Americas and the World Project, we show that the Brazilian public, coping with an extraordinarily confusing world with limited informational resources, is still able to structure their views about foreign policy using their own normative beliefs about the role of Brazil in the world.

\section{Structuring Attitudes in Brazil: The Concepts}

In this section, we develop our conceptual understanding of the constructs using the Hurwitz and Peffley (1987) model. We also justify the conceptual choices for each construct-core values, postures, and specific foreign policy preferences-using the literature on Brazilian foreign policy.

Hurwitz and Peffley (1987) assume that because humans have severe cognitive limitations, they often behave as cognitive misers. In other words, when facing the complex issues of world affairs, individuals

\footnotetext{
${ }^{2}$ Indeed, the perception that foreign affairs were something that only the specialized elite was capable of understanding and, consequently, dominating has been discussed extensively by the literature in Brazil. However, most studies were focused on how Itamaraty-, the Brazilian Ministry of Foreign Affairs, was efficiently insulated from organized interests and not how the public perceived international affairs (Faria 2008, 2012; Lopes 2010).
} 
resort to cognitive shortcuts that simplify their decisions, despite their informational disadvantage. These shortcuts derive from their normative beliefs and core values developed over the years.

Based on an information-process perspective, in which an individual's reliance on simplification is assumed to increase with complexity of the environment, Hurwitz and Peffley (1987) suggest a three-layered analytical model in which preferences for specific foreign policy issues are framed by prior postures that citizens possess, which inform their view of how their nation should behave in the international arena. These postures, gradated from acceptance to rejection, provide criteria for citizens to assess actual governmental initiatives regarding concrete issues, despite their informational limitations. In the end, these postures' preferences are rooted in core values expressing world views that are predominant among citizens.

Hurwitz and Peffley's model suggests that core values and abstract postures are related to a long-established domestic debate in the United States involving foreign affairs such as animosity toward the Soviet Union or the myth of American exceptionalism in the world. The same logic applies to the domestic debate in Brazil, where diplomats, academics, and intellectuals have discussed for decades the appropriate role for Brazil in international affairs. We show here that local debates about Brazilian foreign policy among policy makers, specialists, and scholars alike have created a broad conceptual framework for helping organize how the Brazilian public, with scant knowledge or information, understands those same issues.

\section{Core beliefs}

The two most fundamental core beliefs shared by the Brazilian public about the country's orientations in world affairs are international protagonism and pacifism. The literature about Brazil's foreign policy shows that these two principles are intrinsically embedded in a diplomatic discourse that praises Brazil as a country at peace with its neighbors and willing to be a prominent and influential actor on the world stage. These principles express profound historical visions advocated by every Brazilian administration since the late nineteenth century. Diplomats and intellectuals alike sustain that pacifism and protagonism are moral cornerstones of Brazil's position in the world (Ricupero 2000, 2017a, 2017b; Lafer 2001; Corrêa 2000).

More precisely, pacifism represents a vision in which Brazil should pursue diplomacy and peaceful solutions to military conflicts in all scenarios. The myth of a peaceful country has been embedded in the official diplomatic rhetoric since the times of the legendary Barão do Rio Branco, minister of foreign relations from 1902 to 1912. The same vision can be found in Ruy Barbosa's (1849-1923) intellectual contribution, especially his speech to the Second Peace Conference at The Hague, in 1907, in which he praises Brazil's peaceful vocation. In the Brazilian diplomatic mythology, these two leaders embodied the country's pacifism and the inclination to favor negotiated solutions to international conflicts, receiving constant accolades in current speeches and narratives by contemporary diplomats (Cunha 1977; Cardim 2017; Ricupero 2017b).

International protagonism refers to Brazil's continuous claim for recognition as an important player in world affairs. The literature on Brazil's foreign policy continually discusses its search for global reputation and recognition as a world power, especially by Europe and the United States (Lafer 2001; Burges 2005; and Lima 2005). According to Lima $(2005,5-6)$, there is a long-lasting belief, shared by the Brazilian elites, that the country is destined to play a significant role in world affairs and that it deserves the recognition of this capacity by the major world powers.

In this context, the aspiration to become a world power has been usually associated, since the politica externa independente of Jânio Quadros and João Goulart (1961-1964), with antagonist policies toward the United States. To become an important global player, Brazil should seek counterhegemonic strategies that defied the US position in the world (Vigevani and Cepaluni 2007; Fonseca 1998). In contrast, having a closer relationship with the United States, something usually associated with the concept of alignment, has been rarely seen, in the history of the Brazilian foreign policy, as the best strategy to increase global influence (Moura 1985; Casarões 2014).

\section{Normative postures}

At the intermediate level, we introduce normative beliefs expressed in postures regarding the role of the Brazilian state and the possibilities for governmental action in the international system. Postures are related to general directions or orientation that the government should adopt in international politics. They also serve as broad representations that structure ideas about foreign policy involving practical strategic orientations for governmental actions. In this context, we identified three postures related to Brazil's behavior abroad: multilateralism, Americanism, and regionalism.

The first posture, multilateralism, means the support for foreign policy orientations whose goal is to strengthen multilateral institutions. Brazil's long-standing adherence to the principle of multilateralism 
has become a flagship of the country's foreign policy and international identity. Fonseca $(2008,2014)$, a prominent diplomat and intellectual, highlights that the Brazilian diplomatic discourse has historically stated its support for multilateralism and the need to strengthen international institutions as an alternative to power politics. Discussing Brazil's historical foreign policy orientations, the former minister of foreign affairs, Celso Lafer $(2000,12)$, also argued that multilateral arenas constitute the "best chessboard for the country to exercise its national interests" protecting it from asymmetrical bilateral relations.

The second posture, Americanism, expresses the importance of the United States to the Brazilian foreign policy. Having a closer and strategic relationship with the United States dates back to Barão do Rio Branco's tenure at Itamaraty when he acted to change Brazil's inclination from Europe to the United States in the early twentieth century (Lafer 2000; Ricupero 2017a). Since then, the idea of Americanism has become an important source of controversy and dispute among scholars and diplomats over to which extent Brazil should follow the United States in global affairs or, conversely, to stay autonomous and distant, especially in Latin America. Nevertheless, every administration since Barão do Rio Branco has had to design a specific foreign policy toward the United States, either aligning itself with or distancing itself from Washington (Hirst 2006; Almeida and Barbosa 2006; Lima 2005).

The third posture, regionalism, is related to the importance of Latin America to Brazil's aspirations as a global power and whether the country should exercise regional leadership and support regional integration as a way to reach global protagonism. Although regionalism became a critical topic much later than the previous two postures, it gained prominence in the past thirty years as a result of MERCOSUR and other institutional developments in Latin American.

The literature shows a relatively stable domestic support for regionalism (Mourón, Urdinez, and Onuki 2016; Onuki, Mourón, and Urdinez 2016), and many scholars have pointed out the growing importance of Latin America to Brazil's strategic thinking and domestic debates, as well as for the role of regional leader (Vigevani and Ramanzini 2010; Bueno, Ramanzini Júnior, and Vigevani 2014; Guimarães, Fernandes, and Maldonaldo 2020; Malamud 2011; Mourón, Urdinez, and Onuki 2016; Almeida 2016; and Flemes 2010).

\section{Specific foreign policy issues}

We have chosen four specific policy issues that in the past decades have been central to the Brazilian foreign policy agenda and diplomatic rhetoric: the bilateral relationship with the United States, SouthSouth diplomacy, multilateral foreign policy initiatives, and the relationship with Latin American countries. In each dimension, we included survey questions about concrete and more recent foreign policy initiatives, as well as about images regarding specific countries, such as the United States, India, and China.

First, the bilateral relationship between Brazil and the United States has been extensively studied in the literature (Amorim Neto 2012; Bandeira 2004; Hirst 2006). Studies on Brazilians' perceptions of the United States have shown a reasonably positive, consistent, and stable view since the early 1960s (Loureiro, Guimarães, and Schor 2015; Mourón, Urdinez, and Onuki 2016; Souza 2008). In this sense, we build this category looking into to which degree Brazilians perceive the importance of this relationship.

Second, South-South diplomacy has become a cornerstone of Brazil's foreign policy in the past two decades. It is fair to say that since Lula da Silva's administration (2002-2010) Brazil has pivoted more prominently toward China, Russia, and African countries to counterbalance US influence in global affairs (Vigevani and Cepaluni 2007; Burges 2005). We build this category looking at the level of support for SouthSouth cooperation.

Third, as we have already mentioned, the commitment to multilateralism has been a linchpin of Brazil's foreign policy since the 1960s. More recently, Brazil has pushed for a permanent seat at the UN Security Council, fully supported the creation of the UN Human Rights Council, and actively participated in UN organizations, such as the World Health Organization and Food and Agriculture Organization. The same can be said regarding the participation in the Bretton Woods institutions and the system of the General Agreement on Tariffs and Trade and the World Trade Organization (Almeida 2016; Reynolds 2017). We build this category using level of support for the United Nations.

Fourth, the relationship between Brazil and its Latin American neighbors has become increasingly important with the creation of UNASUR (Union of South American Nations) in 2008, CELAC (Community of Latin American and Caribbean States) in 2010, and Lima Group in 2017. During the presidencies of Lula (2002-2010) and Dilma Rousseff's (2011-2016), it became clear that the country's neighborhood and its new institutional arrangements were part of a broader strategy to turn Brazil into the political center of the region with less US influence (Vigevani and Cepaluni 2007; Malamud 2011; Flemes 2010). We build this category looking at the level of support for regional integration. 


\section{Structuring Attitudes in Brazil: The Model}

In this section, we present how we build each latent concept using survey questions from 2014 and 2019 and discuss our expectations of the relationships between the concepts in the established framework, listing them in descending order of abstraction. ${ }^{3}$ We also present descriptive data, methodology, and model specification.

Each core value has a potential effect on each normative posture. In turn, each posture has a potential effect on each specific policy preference. The model assumes that the three postures mediate all core values' effects on specific policy preferences. At the end of the section, we show which relations are more relevant to the model.

\section{Building core beliefs}

Core beliefs are the main exogenous concepts of our analysis, affecting postures that, in turn, affect attitudes about specific foreign policy actions. There are two core beliefs: protagonism and pacifism.

Protagonism signals an active role Brazil should play in world affairs. To measure it, we used three different survey questions from both samples. The respondents were asked whether Brazil should (1) have active participation or to stay away from world affairs, (2) seek to be a regional leader, and (3) how important is Brazil in international affairs.

We expect that protagonism will affect all postures. The aspiration for Brazil's active role in world politics is expected to be related to more robust support for multilateralism and regionalism. We also expect that the preference for more protagonism in world affairs will be negatively related to positive attitudes toward the United States.

Pacifism displays the preference for diplomacy and peaceful solutions to international conflicts. To measure pacifism, we used three different survey questions from both samples. The respondents were asked whether Brazil should increase its influence in world affairs using (1) military power, (2) diplomacy, or (3) trade.

Pacifism should be positively related to all postures. A pacifist view of the Brazilian role in world affairs should be related to a robust multilateral stance and, because Brazil does not have any important border disputes with its neighbors, support for regionalism should be seen as peaceful. We also expect pacifism to be positively related to a positive view of the United States, as Brazil does not have any strategic or military antagonism with that country.

\section{Building postures}

Postures are composed of attitudes toward general government directions in international affairs. We selected multilateralism, Americanism, and regionalism as the main postures for the Brazilian foreign policy.

Multilateralism refers to the support for multilateral institutions as an essential instrument to deal with international challenges. To measure it, we used three questions from both surveys. The first two questions are related to the role and relevance of the United Nations in dealing with peacekeeping missions and the human rights agenda. The third expresses the public support for Brazil's position as the representative of Latin America at the UN Security Council. We expected that multilateralism should be positively related to all four specific foreign policies.

Americanism refers to positive or negative attitudes toward the United States. We selected two questions from both surveys to measure it. The first question is related to feelings of admiration or contempt toward the United States. The second asks respondents to position themselves on a continuum from 0 to 100 of favorable or unfavorable perceptions about the United States. We expect Americanism to be positively related to the US-Brazil relationship but negatively related to the other three specific foreign policy constructs.

Finally, regionalism is related to the importance given to regional integration. In both samples, we used three questions concerning attitudes toward the political integration of South America. The first two questions measure the support for establishing a South American parliament and a common foreign policy for the region. The third question asks whether respondents agree with the free movement of peoplewithout border controls-in the region. We expected regionalism to be negatively related to the US-Brazil relationship but positively related to the other three categories.

\footnotetext{
${ }^{3}$ For the specific survey questions selected for each category, see Appendix 1, item 02 (English and Portuguese)
} 


\section{Building specific policy preferences}

Specific policy preferences refer to four types of concrete foreign policy behavior in the following areas: (1) South-South diplomacy, (2) the US-Brazil bilateral relationship, (3) the Latin America-Brazil relationship, and (4) multilateral institutions.

To measure attitudes toward specific policy preferences on South-South diplomacy, we selected three questions. Two are related to how Brazilians describe the country's relationship with China and India; the third is about the importance of establishing new embassies and consulates in other countries, especially in African countries.

To measure the preferences regarding specific policies toward Latin America, we included two questions. The first question is about how Brazilians perceive the importance of promoting regional integration as a foreign policy goal. The second question asks about the region of the world where Brazil should focus its attention. Our dummy indicator was whether Brazilians prefer the government to be attentive to Latin American against any other region.

To measure support for concrete policies toward the United States, we included different questions depending on the survey. First, we selected one question found in both samples on whether the human rights situation in Brazil would improve under the supervision of the United States. We use two other questions for the 2014 survey. The first one is about how Brazilians describe the relationship between the two countries, and the second is about how to classify the relation between the two countries in terms of friendship, partnership, rivalry, or threat. Finally, for the 2019 sample, we used a question related to whether Brazilian foreign policy should be aligned to that of the United States.

Finally, the last dimension is specific policy attitudes toward multilateral institutions. To measure this, we included two questions for both samples. The first question is whether Brazil should improve its participation in the United Nations, and the second is whether Brazil should accept UN decisions that go against its national sovereignty. For the 2014 sample, we also included a question in which respondents showed their view about the United Nations (unfavorably to favorably) on a scale from 0 to 100.

\section{Methodology}

We use confirmatory factor analysis (CFA) to estimate the hierarchical model of foreign policy attitudes. CFA is a reasonable method to test whether measures of latent variables-our constructs-are consistent with their theoretical understanding. The CFA tests two aspects. First, whether the data fit a hypothesized measurement model. Second, whether it is possible to test a series of simultaneously interdependent relations among the theoretical constructs within a structural equation model (Hair et al. 2009).

After estimating the model, we obtain the fit statistics to assess how well the proposed model has captured covariance between all the constructs and measures of the model. ${ }^{4}$ Also, we analyzed in depth all relations estimated. It is important to highlight that, although CFA is not the best technique to produce specific relation tests, it is a critical tool for analyzing the overall outline of the structure of public opinion as proposed through the hierarchical order of core values, postures, and specific foreign policy preferences.

\section{Model specification}

Following Hurwitz and Peffley (1987), our model assumes that more abstract attitudes constrain concrete ideas. Each of the postures is assumed to be constrained by both core values. Furthermore, each of the specific policy attitudes is assumed to be constrained by all four of the postures. The postures mediate the effects of the core values on the specific policy attitudes. ${ }^{5}$

In Table 1, we describe all indicator variables and their respective constructs for the three levels of attitudes and beliefs, respectively. Almost all variables are measured on an ordinal scale, except for the UN and US approval ratings. Those variables were presented to respondents on a scale from 0 to 100 and reduced to 0 to 1 in our analysis.

\footnotetext{
${ }^{4}$ Hair et al. (2009) highlights the importance of the theoretical framework supporting the model, as structural equation modeling is a confirmatory and not exploratory analysis. It is useful to test whether there is evidence that confirms the theory. All relations should be specified before the model is estimated.

${ }^{5}$ We assume that there can be covariance between two specific policy preferences: foreign policy toward the US and multilateral foreign policy.
} 
Table 1: Data and measurement indicator description.

\begin{tabular}{|c|c|c|}
\hline Latent concept & Indicator & Measurement criteria \\
\hline \multicolumn{3}{|l|}{ Core values } \\
\hline \multirow[t]{3}{*}{ Pacifism } & Military power & $0-4$, totally disagree to totally agree \\
\hline & Diplomacy & $0-4$, totally disagree to totally agree \\
\hline & Trade diplomacy & $0-4$, totally disagree to totally agree \\
\hline \multirow[t]{3}{*}{ Protagonism } & Active participation & $0-2$, stay itself away to active participation \\
\hline & Brazil's importance & $0-4$, nothing important to very important \\
\hline & Leadership LA & $\begin{array}{l}0-2 \text {, keep itself away, collaborate without being leader, to } \\
\text { be regional leader }\end{array}$ \\
\hline \multicolumn{3}{|l|}{ Postures } \\
\hline \multirow[t]{3}{*}{ Multilateralism } & $\begin{array}{l}\text { UN involvement peace } \\
\text { missions }\end{array}$ & $0-2, N G, N G$ at regional organizations, $N G$ at UN \\
\hline & $\begin{array}{l}\text { UN involvement human } \\
\text { rights }\end{array}$ & $0-2, N G, N G$ at regional organizations, $N G$ at UN \\
\hline & UN Security Council seat & $0-1$, another or Brazil \\
\hline \multirow[t]{3}{*}{ Regionalism } & Free movement of persons & $0-4$, totally disagree to totally agree \\
\hline & South American parliament & $0-4$, totally disagree to totally agree \\
\hline & Common foreign policy & $0-4$, totally disagree to totally agree \\
\hline \multirow[t]{2}{*}{ Americanism } & Sentiments to US & $0-2$, contempt to admiration \\
\hline & Favorable opinion to US & $0-1$, continuous variable \\
\hline \multicolumn{3}{|c|}{ Specific policy preferences } \\
\hline \multirow{2}{*}{$\begin{array}{l}\text { Latin America-Brazil } \\
\text { relationship }\end{array}$} & Attention LA & $0-1$, another or Latin America \\
\hline & Regional integration & $0-4$, nothing important to very important \\
\hline \multirow{4}{*}{$\begin{array}{l}\text { Multilateral foreign } \\
\text { policy }\end{array}$} & Acceptance of UN decisions & $0-2$, disagree to agree $(2014)$ \\
\hline & & $0-4$, totally disagree to totally agree (2019) \\
\hline & Favorable to UN (2014) & $0-1$, continuous variable \\
\hline & Brazil-UN relations & $0-4$, nothing important to very important \\
\hline \multirow{3}{*}{$\begin{array}{l}\text { South-South } \\
\text { diplomacy }\end{array}$} & New consulates & $0-4$, nothing important to very important \\
\hline & China-Brazil & $0-2$, threat/rivalry to friendship/society \\
\hline & India-Brazil & $0-2$, threat/rivalry to friendship/society \\
\hline \multirow{5}{*}{$\begin{array}{l}\text { US-Brazil } \\
\text { relationship }\end{array}$} & US-Brazil description (2014) & $0-2$, threat/rivalry to friendship/society \\
\hline & US-Brazil classification (2014) & $0-4$, very bad to very good \\
\hline & US-Brazil human rights & $0-4$, nothing to a lot (2014) \\
\hline & & $0-2$, no, indifference, yes (2018) \\
\hline & US-Brazil alignment (2019) & $0-4$, nothing important to very important \\
\hline
\end{tabular}

Note: $\mathrm{NG}=$ national government.

We adopted three strategies to deal with respondents' missing data problems. For ordinal categorical variables, we use the neutral category as equivalent to the missing data. For the continuous variables, we attributed the average value. For those ordinal questions that did not present a neutral answer, we keep the missing data. ${ }^{6}$ Furthermore, we assume that the ordinal categories behave as interval scales.

\footnotetext{
${ }^{6}$ We estimated the structural equation modeling equations assuming the missing data for those categories are a function of other covariates. Hence, we did not lose the information of the other covariates, as it could be at the most common casewise deletion strategy. The overall results for the 2019 sample are almost the same for both estimations, but by casewise deletion, we lost 234 respondents for all other covariates.
} 
Figure 1 shows the stable relations between core values, normative postures, and specific foreign policy issues. We define stability as those relations that are statistically significant in both models.

\section{Results}

The results-the standardized epistemic correlations-of the measurement model for the nine latent constructs are presented in Table 2. In Table 3, we present structural correlations among the three levels of attitudes. Generally, the indicators-the survey questions-appear to be reliable measures of our theoretical constructs. The mean $\mathrm{R}^{2}$ of the indicators is 0.23 ( 0.22 for 2014; 0.24 for 2019); all are significantly related to the theoretical construct. The $\mathrm{R}^{2}$ of the construct is also reasonable. The mean value is 0.5 ( 0.54 for $2014 ; 0.45$ for 2019), and if we exclude the two indicators with higher values, the mean remains relatively high: 0.36 .

Besides, the overall fitting statistics indicate that the proposed hierarchical model fits the data. ${ }^{7}$ The root mean square error of approximation are of 0.050 (90 percent confidence interval [CI]: 0.047-0.052) for 2014 and 0.059 (90 percent CI: 0.057-0.062) for 2019, which indicate goodness of fit (Hu and Bentler 1999; Browne and Cudeck 1993). ${ }^{8}$

\section{Structural model}

The most important result we found is the high level of interconnectedness and structure between foreign policy elements at two different points in time. Attitudes and preferences for specific policy levels are tied to constructs of a higher level of abstraction-postures and core values. Even though not all connections are statistically significant, most of them are quite robust, at twelve for 2014 and fifteen for 2019 out of the eighteen proposed relations.

At the postural level, for example, there are secure connections between the postures and one or both of the core values ideas (protagonism and pacifism). The same happens for specific preferences for foreign policy issues. Both constructs that include questions about multilateralism-the posture for multilateralism and the specific issue preferences for a multilateral foreign policy-are correlated at a very high level, as expected. All other postures and specific foreign policy preferences are related to some of their respective higher-level constructs. It is interesting that regionalism is not correlated with the specific policy preference for Latin America in both surveys. In the 2019 survey, regionalism notably is correlated with the other three specific policy preferences.

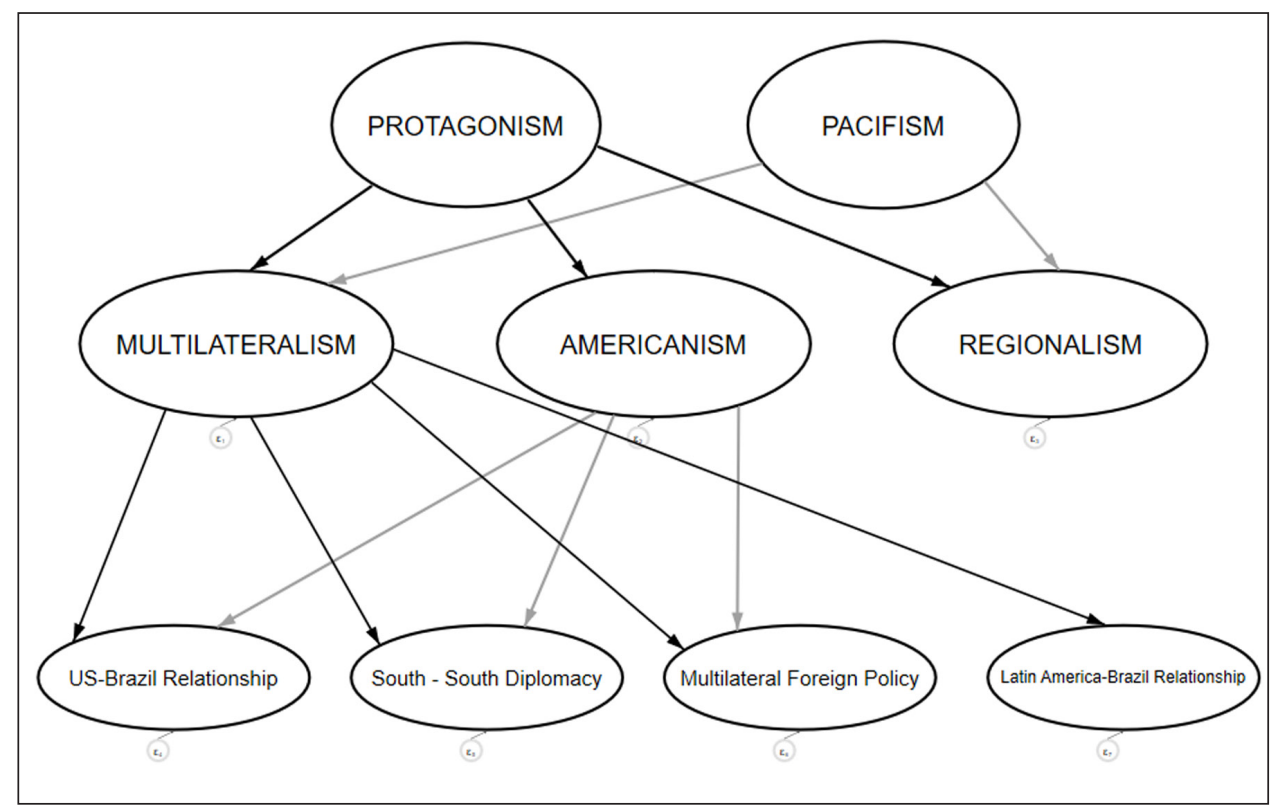

Figure 1: Path diagram: stable relations.

\footnotetext{
${ }^{7}$ For a better explanation on the overall fitting, see Appendix 1, item 03.

${ }^{8}$ The covariance term is significant just for the 2019 model. If we exclude it from the 2014 survey, there is no improvement or weakening of the RMSEA statistics. We choose to keep it to have the same structural model for both surveys. For different estimations using factor analysis and seemingly unrelated regression models, see Appendix 1, item 03.
} 


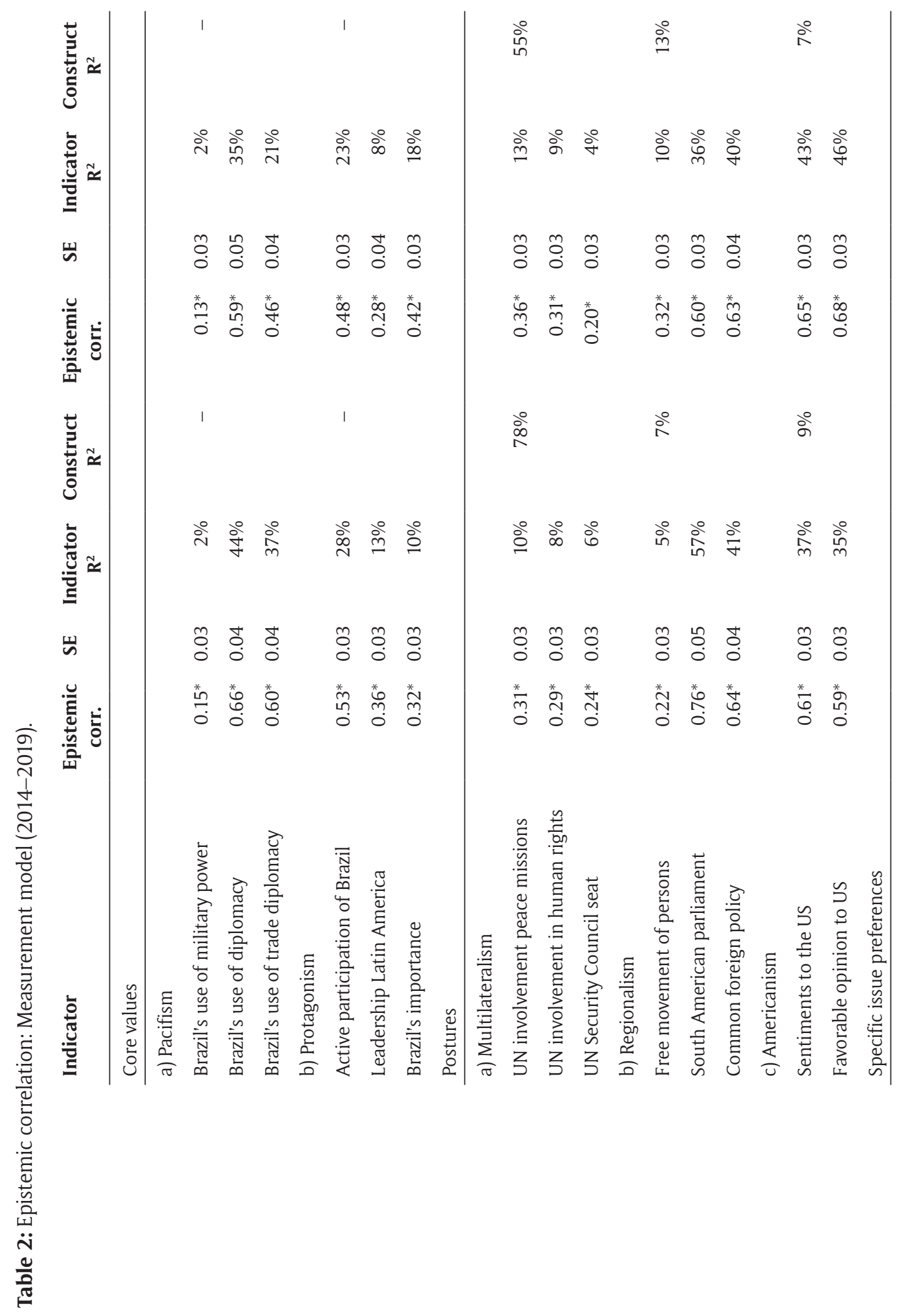




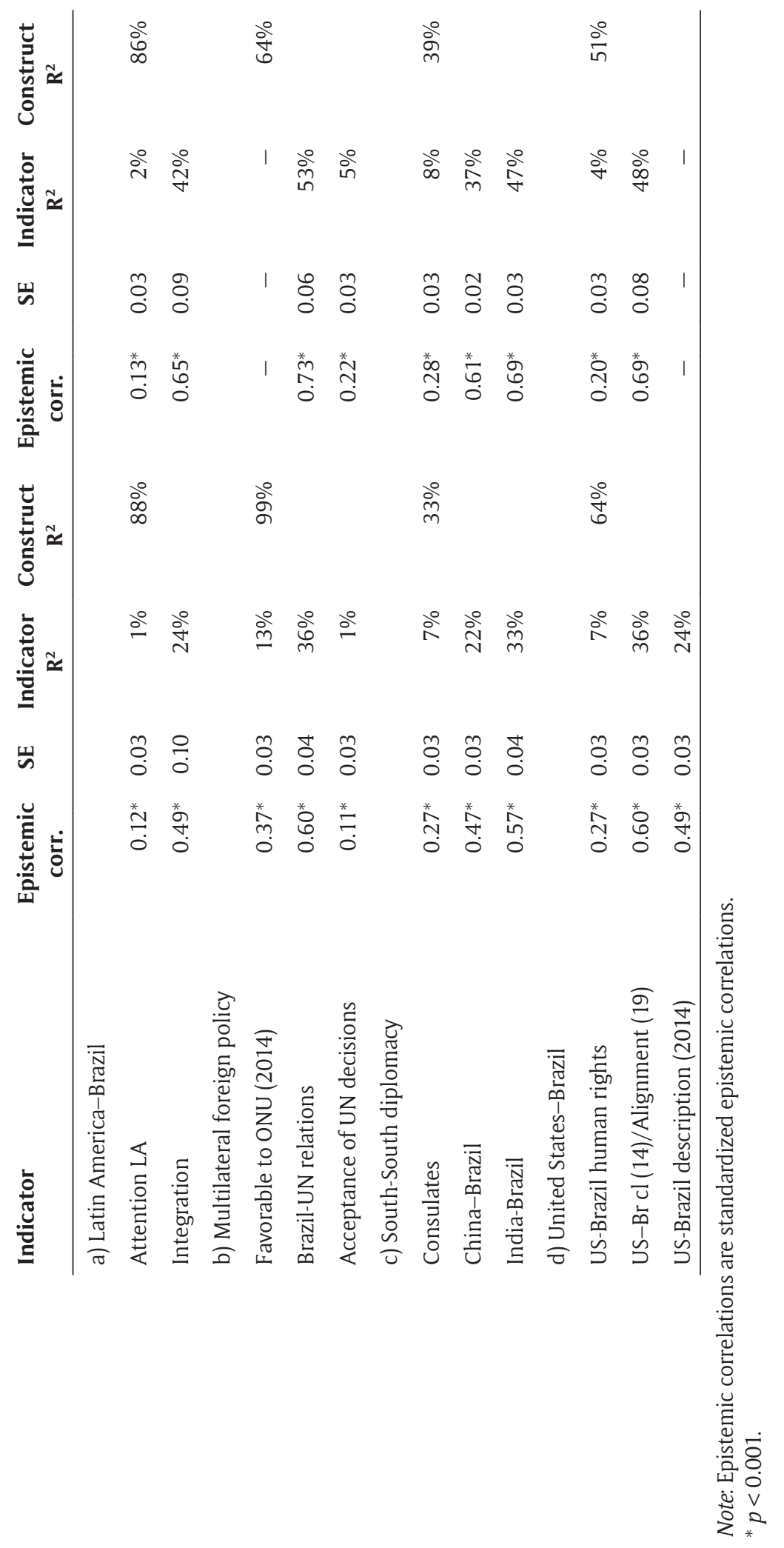


Table 3: Hierarchical structural model.

\begin{tabular}{|c|c|c|c|c|c|}
\hline & & $\begin{array}{l}\text { Standardized } \\
\text { betas }(2014)\end{array}$ & $\begin{array}{c}\text { Standard } \\
\text { error }(2014)\end{array}$ & $\begin{array}{l}\text { Standardized } \\
\text { betas }(2019)\end{array}$ & $\begin{array}{c}\text { Standard } \\
\text { error }(2019)\end{array}$ \\
\hline \multicolumn{6}{|c|}{ Specific issue preferences } \\
\hline \multirow{3}{*}{$\begin{array}{l}\text { Latin } \\
\text { America-Brazil } \\
\text { Relationship }\end{array}$} & Multilateralism & $0.950^{* * *}$ & 0.187 & $0.896^{* * *}$ & 0.126 \\
\hline & Regionalism & 0.061 & 0.061 & 0.072 & 0.058 \\
\hline & Americanism & $-0.132^{+}$ & 0.071 & 0.039 & 0.051 \\
\hline \multirow{3}{*}{$\begin{array}{l}\text { Multilateral } \\
\text { foreign policy }\end{array}$} & Multilateralism & $0.846^{* * *}$ & 0.050 & $0.741^{* * *}$ & 0.064 \\
\hline & Regionalism & 0.015 & 0.045 & $0.125^{*}$ & 0.055 \\
\hline & Americanism & $0.351^{* * *}$ & 0.068 & 0.058 & 0.044 \\
\hline \multirow{3}{*}{$\begin{array}{l}\text { South-South } \\
\text { diplomacy }\end{array}$} & Multilateralism & $0.501^{* * *}$ & 0.049 & $0.439^{* * *}$ & 0.039 \\
\hline & Regionalism & 0.051 & 0.043 & $0.131^{* *}$ & 0.042 \\
\hline & Americanism & $0.155^{* * *}$ & 0.048 & $0.299^{* * *}$ & 0.037 \\
\hline \multirow{3}{*}{$\begin{array}{l}\text { US-Brazil } \\
\text { relationship }\end{array}$} & Multilateralism & $0.237^{* * *}$ & 0.047 & $0.336^{* * *}$ & 0.051 \\
\hline & Regionalism & $0.074^{+}$ & 0.040 & $0.177^{* *}$ & 0.056 \\
\hline & Americanism & $0.692^{* * *}$ & 0.047 & $0.499^{* * *}$ & 0.081 \\
\hline \multicolumn{6}{|l|}{ Postures } \\
\hline \multirow[t]{2}{*}{ Multilateralism } & Protagonism & $0.772^{* * *}$ & 0.053 & $0.653^{* * *}$ & 0.053 \\
\hline & Pacifism & $0.425^{* * *}$ & 0.040 & $0.352^{* * *}$ & 0.047 \\
\hline \multirow[t]{2}{*}{ Regionalism } & Protagonism & $0.109 * *$ & 0.042 & $0.263^{* * *}$ & 0.048 \\
\hline & Pacifism & $0.240^{* * *}$ & 0.038 & $0.254^{* * *}$ & 0.047 \\
\hline \multirow[t]{3}{*}{ Americanism } & Protagonism & $0.291^{* * *}$ & 0.047 & $0.244^{* * *}$ & 0.046 \\
\hline & Pacifism & 0.065 & 0.041 & $0.106^{*}$ & 0.045 \\
\hline & $N$ & 1881 & & 1849 & \\
\hline
\end{tabular}

${ }^{* * *} p<0.001 ;{ }^{* *} p<0.01 ;{ }^{*} p<0.05 ;+p<0.1$.

As the $\mathrm{R}^{2}$ indicated in Table 2, a substantial proportion of variation in most of the endogenous constructs is explained by more abstract beliefs. At the specific policy levels, the variations of $R^{2}$ vary from 33 percent observed for the South-South diplomacy construct to 99 percent for multilateral foreign policy.

This is a significant empirical result with crucial theoretical implications. The estimated hierarchical model confirms the existence of structure and consistency of foreign policy attitudes both in 2014 and 2019 surveys, with almost similar models. Our results indicate that when the constraint is measured as a series of vertical relationships between attitudes at different levels of abstraction, the degree of structure on the Brazilians foreign policy attitudes is consistent and structured over time.

\section{Core values and postures}

The relationships uncovered in the first type of relationship between core values and postures provide valuable insight into the various ways that core values anchor the public's view and guide their foreign policy attitudes. Moreover, for the most part, the linkages that emerge are reasonably consistent with our conceptualization.

We found that respondents supporting protagonism are likely to endorse multilateralism more often ( $\beta=0.8$ and 0.7, for 2014 and 2019, respectively). They have a more favorable view of the United States ( $\beta=0.3$ and 0.2 ), which is against our prediction that favoring the United States means less protagonism for Brazil in world politics. There is also a strong relation between protagonism and regionalism, which was expected, as a more protagonist stance should be associated with positive views about regional integration $(\beta=0.1$ and 0.3$)$.

As expected, supporting pacifism also means support for multilateralism ( $\beta=0.4$ and 0.4$)$, and for regionalism ( $\beta=0.2$ and 0.3 ). On the other hand, we could not find any stable relationship between pacifism and Americanism, something that we initially expected. 


\section{Postures and specific issues}

The other important dimension of our model is the links between postures and specific foreign policy issues. First, we found many stable relations in both models (2014 and 2019). Multilateralism is the main connection for Latin America-Brazil relationship ( $\beta=0.9$ and 0.9), which is something expected since the relationship with Latin American countries usually entails regional institutional making.

In the same vein, multilateral foreign policy is strongly connected to multilateralism in both models ( $\beta=0.8$ and 0.7 ) but not consistently connected to the other two postures of Americanism and regionalism. We expected the lack of connection between multilateral foreign policy and Americanism, because favoring the United States usually means unilateralism rather than multilateralism. Nevertheless, the disconnection between multilateral foreign policy and regionalism is rather striking because one expects the support for regionalism to be consistent with institutional making and support. To be fair, however, multilateral foreign policy has some correlation with Americanism in the 2014 survey $(\beta=0.4)$ and with regionalism in $2019(\beta=0.1)$.

Furthermore, regionalism is not connected to Latin America-Brazil in either survey. This is unexpected for obvious reasons: we would expect that favoring regionalism would also mean favoring more concrete relationships with Latin American countries, but this appears not to be the case. Americanism is not connected to Latin American-Brazil either, but this is somewhat expected because favoring the United States would usually mean moving away from other Latin American countries.

Both multilateralism and Americanism are consistently linked to the other two specific policy preferences, South-South diplomacy and US-Brazil relationship. These findings are also somewhat counterintuitive, as a multilateral approach in global affairs should not necessarily represent strong support for the United States ( $\beta=0.2$ and 0.3 ). Besides, Americanism being related to the support for South-South diplomacy $(\beta=0.2$ and 0.3 ) is something not expected and challenging to comprehend. South-South diplomacy usually means counterhegemony strategies and not favoring the United States. The expected effects of multilateralism on South-South diplomacy ( $\beta=0.5$ and 0.4 ) and of Americanism on the US-Brazil relationship ( $\beta=0.7$ and 0.5 ) are higher.

\section{Conclusion}

How do individuals in Brazil make sense of a complex international environment given their low levels of information on international affairs? We resisted answering this question with models that emphasize exogenous cognitive shortcuts to understand world politics, such as party lines or ideology. Instead, we used an intensive and domain-specific approach in which foreign policy attitudes are connected to core values and postures from within the domain of international relations' values and beliefs. More precisely, we found out that Brazilians' attitudes on many specific foreign policy issues are predicted by more general foreign policy postures, that is, generalized preferences for the conduct of foreign policy. In turn, preferences for these postures are affected by two more rooted foreign policy beliefs, protagonism and pacifism.

Our findings suggest that earlier studies in Latin America (Castillo, Maldonado, and Shiavon 2015) that showed international attitudes as related to a realist-liberal dimension are not definitive evidence that foreign policy attitudes in Latin America are structured around exclusively those lines. On the contrary, our study shows that general attitudes that constrain specific foreign policy preferences can be related to local dimensions of foreign policy ideological debates, such as protagonism and pacifism.

More importantly, our study provides strong evidence against those analysts and pundits who have argued that the nature of political opinion on foreign policy in Brazil was random or disorganized (Albuquerque 1998; Souza 2008). Instead, our findings suggest that the structure of foreign policy attitudes in Brazil are not the result of some random correlations but of something more stable and consistent over time.

A more recent analysis of Hurwitz, Peffley, and Seligson (1993) revealed that, in the case of another Latin American country (Costa Rica), public attitudes were structured by core beliefs and postures that originated within the foreign policy domain. Likewise, our study corroborates the notion that structure and consistency are more ubiquitous in Latin America than previously thought.

In this context, postures used to anchor individuals' specific policy preferences should prove to be crucial analytical guidelines for future efforts to interpret and predict mass reactions to foreign policy events in Brazil. This assessment follows Hurwitz and Peffley (1987). That is, analyzing these postures should prove more powerful and more parsimonious for scholars and analysts to understand how citizens perceive foreign affairs than focusing on opinions about specific issues, which can change over time. The Brazilian case seems to reconfirm this. 
Our specific empirical findings are as follows. First, the influence of protagonism as a core value has interesting results in both surveys (2014 and 2019). We expected that respondents favoring a protagonist stance for Brazil in global affairs would also support multilateralism as a posture. The finding goes hand in hand with the history of Brazilian foreign policy and its traditional multilateralism, seen by many diplomats as the best strategy to increase Brazil's global influence. The same logic is applied to the connection between protagonism and regionalism. The literature is almost unanimous in pointing out that only a robust regional policy gives Brazil the credentials to be a global power.

However, we did not expect a strong connection between protagonism and Americanism. Based on the literature, we expected that respondents favoring protagonism would most certainly reject a closer relationship with the United States. The literature on Brazilian foreign policy almost unanimously argues that any alignment with the United States means less influence for Brazil in many international fora. But the results suggest that protagonism is more ubiquitous than we expected. It seems that Brazilians tend to support a very active foreign policy, including support for multilateralism, regionalism, and Americanism if the final result means more influence for Brazil in global affairs.

Second, pacifism has a more precise and more consistent influence on other constructs in both surveys (2014 and 2019). As expected, pacifists in Brazil support multilateralism and regionalism and do not support a closer relationship with the United States. It seems that pacifists in Brazil have an unhindered view of Brazil's most important postures for sustaining peaceful global affairs: support multilateral institutions, and stay away from the United States. It is important to remember that this last connection is contrary to our initial expectations. We initially thought that since Brazil does not have any strategic or security-related issues with the United States, local pacifists would perceive a closer relationship in a more favorable fashion. That does not seem to be the case.

Third, the widespread ramifications of multilateralism (2014 and 2019) only reinforce the idea that Brazilian foreign policy is multilateralist, a characteristic now widely supported by the public. Multilateralism is affected by both core values and influences all specific foreign policies. It seems that Itamaraty's long history of supporting multilateralism has paid off with the public.

Fourth, Americanism has proved an important construct not only for those who are pacifists but also for those who favor protagonist positions. We expected protagonism and Americanism to be antithetical, but that was not the case. It seems that the Brazilian public perceives a closer relationship with the United States as a stepping-stone to global influence. Furthermore, Americanism's strong connections with South-South diplomacy (2014 and 2019) and connection with multilateral foreign policy (2014) shows that support for the United States is more widespread among the Brazilian public than initially discussed by the literature on Brazilian foreign policy.

Finally, regionalism has somewhat ambiguous ramifications. We expected that respondents favoring regionalism would also favor Latin America-Brazil, multilateral foreign policy, and South-South diplomacy, but that is not the case. Regionalism does not explain much of the connection for specific foreign policy issues. It is connected to protagonism and pacifism, which makes it an integral part of the model, but it does not render much information on whether the preference for regional politics matters for the Brazilian public.

In sum, our model and empirical results show that Brazilian attitudes toward foreign policy issues are structured, consistent, and coherent. These new findings have shown that it is not possible to abide by the famous 1986 quote of Ulysses Guimarães, former president of the National Congress: "Itamaraty only gains vote in Burundi" (Gaspari 2010). It seems that it might be gaining in Brazil as well.

\section{Additional File}

The additional file for this article can be found as follows:

• Online Appendix. Appendix 01. DOI: https://doi.org/10.25222/larr.876.s1

\section{Author Information}

Maria Hermínia Tavares de Almeida is senior researcher at Centro Brasileiro de Análise e Planejamento and professor at the University of São Paulo (retired), having taught in the International Relations and Political Science Graduate Program. At the University of São Paulo she has been dean of the Institute of International Relations. She holds a bachelor's degree in social sciences (1969) and a PhD in political science (1979) from the University of São Paulo and made her postdoctoral studies at the University of California, Berkeley (1984). As a political scientist, she conducted research on public policies and Brazilian political institutions, and more recently on public opinion and foreign policy in Brazil. 
Ivan Filipe Fernandes is assistant professor of public policy at the Federal University of ABC, Brazil. He holds a bachelor's degree in international relations (2007) and a master's and PhD in political science from the University of São Paulo (2010). He was a visiting researcher at the University of Illinois at UrbanaChampaign (2012). His research has been published in International Political Science Review, Economics Letters, Foreign Policy Analysis, Development in Practice, Brazilian Journal of Public Administration, Brazilian Political Science Review, and other Brazilian and Latin American journals in international relations and political science. His book A democracia reduz a desigualdade econômica? Um estudo sobre as possibilidades de construção de uma sociedade mais igual por meio da democracia was published by EdUFABC in 2017.

Feliciano de Sá Guimarães is associate professor at the Institute of International Relations at University of São Paulo (IRI-USP). Professor Guimarães was visiting professor at the Political Science Department at Yale University (2019-2020) and program chair for the 2020 International Studies Association Annual Meeting. Guimarães research is focused on foreign policy analysis and public opinion. His research has been published at American Journal of Political Science, Foreign Policy Analysis, Latin American Politics and Society, International Affairs, International Journal, Cambridge Review of International Affairs, Brazilian Political Science Review, and other Brazilian and Latin American journals in international relations and political science. His book A Theory of Master Role Transition: Small Powers Shaping Regional Hegemons was published by Routledge in July 2020.

\section{References}

Albuquerque, José Augusto Guilhon. 1998. “Percepções das elites do Cone Sul sobre as relações internacionais do Brasil." Texto para Discussão No. 693. Brasília: IPEA.

Aldrich, John, Christopher Gelpi, Peter Feaver, Jason Reifler, and Kristin Thompson Sharp. 2006. "Foreign Policy and the Electoral Connection." Annual Review of Political Science, no. 9: 477-502. DOI: https:// doi.org/10.1146/annurev.polisci.9.111605.105008

Almeida, Maria Hermínia Tavares. 2016. “Within the Region, beyond the Region: The Role of Brazil According to the Mass Public." In Foreign Policy Responses to the Rise of Brazil: Balancing Power in Emerging States, edited by Gian Lucca Gardini and Maria Hermínia Tavares de Almeida, 29-45. New York: Palgrave Macmillan. DOI: https://doi.org/10.1007/978-1-137-51669-5_3

Almeida, Paulo Roberto, and Rubens Barbosa. 2006. Relações Brasil-Estados Unidos: Assimetrias e convergências. São Paulo: Editora Saraiva.

Amorim Neto, Octavio. 2012. De Dutra a Lula: A condução e os determinantes da política externa brasileira. Rio de Janeiro: Editora Campus.

Bandeira, Moniz. 2004. As relações perigosas: Brasil-Estados Unidos (de Collor de Melo a Lula). Rio de Janeiro: Editora Civilização Brasileira.

Baum, Matthew, and Philip Potter. 2008. "The Relationships between Mass Media, Public Opinion, and Foreign Policy: Toward a Theoretical Synthesis." Annual Review of Political Science, no. 11: 39-66. DOI: https://doi.org/10.1146/annurev.polisci.11.060406.214132

Baum, Mathew, and Philip Potter. 2015. War and Democratic Constraint: How the Public Influences Foreign Policy. Princeton, NJ: Princeton University Press. DOI: https://doi.org/10.23943/ princeton/9780691164984.001.0001

Baum, Matthew, and Tim Groeling. 2010. "Reality Asserts Itself: Public Opinion on Iraq and the Elasticity of Reality." International Organization 64 (3): 443-479. DOI: https://doi.org/10.1017/ S0020818310000172

Baumgartner, Jody, Peter Francis, and Jonathan Morris. 2008. "A Clash of Civilizations? The Influence of Religion on Public Opinion of US Foreign Policy in the Middle East." Political Research Quarterly 61 (2): 171-179. DOI: https://doi.org/10.1177/1065912907307288

Bjereld, Ulf, and Anne-Marie Ekengren. 1999. "Foreign Policy Dimensions: A Comparison between the United States and Sweden." International Studies Quarterly 43 (3): 503-518. DOI: https://doi.org/ 10.1111/0020-8833.00132

Browne, Michael, and Robert Cudeck. 1993. "Alternative Ways of Assessing Model Fit." Sociological Methods and Research 21 (2): 230-258. DOI: https://doi.org/10.1177/0049124192021002005

Bueno, Clodoaldo, Haroldo Ramanzini Júnior, and Tullo Vigevani. 2014. "Uma perspectiva de longo período sobre a integração latino-americana vista pelo Brasil." Contexto Internacional 36 (2): 549-583. DOI: https://doi.org/10.1590/S0102-85292014000200008

Burges, Sean. 2005. "Auto-estima in Brazil: The Logic of Lula's South-South Foreign Policy." International Journal 50 (4): 1133-1151. DOI: https://doi.org/10.1177/002070200506000415 
Cardim, Carlos Henrique. 2017. "The Root of the Matter: Rui Barbosa-Brazil in the World." In Brazilian Diplomatic Thought, edited by José Vicente Pimentel, 3:457-500. Brasília: FUNAG.

Casarões, Guilherme. 2014. "O tempo é o senhor da razão? A politica externa de Collor vinte anos depois." $\mathrm{PhD}$ diss., University of São Paulo.

Castillo, Rodrigo, Geraldo Maldonado, and Jorge Shiavon. 2015. "To Know or Not to Know? Realist and Liberal Theories on Foreign Affairs and Public Opinion in Latin America." Latin America Policy 6 (1): 2-18. DOI: https://doi.org/10.1111/lamp.12062

Corrêa, Luiz Felipe de Seixas. 2000. "Diplomacia e história: Política externa e identidade nacional brasileira." Política Externa (São Paulo) 9 (1): 22-32.

Cunha, Pedro. 1977. A diplomacia da paz: Rui Barbosa em Haia. Rio de Janeiro: Ministério da Educação e Cultura, Fundação Casa de Rui Barbosa.

Faria, Carlos. 2008. "Opinião pública e política externa: Insulamento, politização e reforma na produção da política exterior do Brasil." Revista Brasileira de Política Internacional 5 (2): 80-97. DOI: https:// doi.org/10.1590/S0034-73292008000200006

Faria, Carlos. 2012. "O Itamaraty e a política externa brasileira: Do insulamento à busca de coordenação dos atores governamentais e de cooperação com os agentes societários." Contexto Internacional 34 (1): 311-355. DOI: https://doi.org/10.1590/S0102-85292012000100009

Flemes, Daniel. 2010. "Brazil Strategic Options in a Changing World Order." In Regional Leadership in the Global System: Ideas, Interests, and Strategies of the Regional Powers, edited by Daniel Flemes, 93-112. Farnham, UK: Ashgate.

Fonseca, Gélson, Jr. 1998. A legitimidade e outras questões internacionais: Poder e ética entre as nações. São Paulo: Paz e Terra.

Fonseca, Gélson, Jr. 2008. O interesse e a regra: Ensaios sobre o multilateralismo. São Paulo: Paz e Terra.

Fonseca, Gélson, Jr. 2014. "Apontamentos para o estudo da diplomacia multilateral do Brasil." PhD diss., Universidade Federal do Rio Grande do Sul.

Fraga, Rosendo, and Pablo Asa. 2010. La opinion pública argentina sobre política exterior y defensa. Buenos Aires: Consejo Argentino para las Relaciones Internacionales.

Gaspari, Elio. 2010. "Serra joga parado, mas quer preferência." Folha de São Paulo, March 3.

Gravelle, Timothy, Jason Reifler, and Thomas Scotto. 2017. "The Structure of Foreign Policy Attitudes in Transatlantic Perspective: Comparing the United States, United Kingdom, France, and Germany." European Journal of Political Research 56 (4): 757-776. DOI: https://doi.org/10.1111/1475-6765.12197

Guimarães, Feliciano, Ivan Fernandes, and Gerardo Maldonaldo. 2020. "Domestic Attitudes toward Regional Leadership: A Survey Experiment in Brazil." Foreign Policy Analysis 16 (1): 98-117. DOI: https:// doi.org/10.1093/fpa/orz002

Hair, Joseph F., et al. 2009. Análise multivariada de dados. Porto Alegre: Bookman Editora.

Herrmann, Richard, Philip Tetlock, and Penny Visser. 1999. "Mass Public Decisions to Go to War: A Cognitive-Interactionist Framework." American Political Science Review 93 (3): 553-573. DOI: https:// doi.org/10.2307/2585574

Hirst, Mônica. 2006. "Os cinco 'as' das relações Brasil-Estados Unidos: Aliança, alinhamento, autonomia, ajustamento e afirmação." In Relações internacionais do Brasil: Temas e agendas, 91-127. São Paulo: Editora Saraiva.

Holsti, Ole. 1992. "Public Opinion and Foreign Policy: Challenges to the Almond-Lippmann Consensus Mershon Series: Research Programs and Debates." International Studies Quarterly 36 (4): 439-466. DOI: https://doi.org/10.2307/2600734

Holsti, Ole. 2004. Public Opinion and American Foreign Policy. Ann Arbor: University of Michigan Press. DOI: https://doi.org/10.3998/mpub.6750

Hu, Litze, and Peter Bentler. 1999. "Cutoff Criteria for Fit Indexes in Covariance Structure Analysis: Conventional Criteria versus New Alternatives." Structural Equation Modeling: A Multidisciplinary Journal 6 (1): 1-55. DOI: https://doi.org/10.1080/10705519909540118

Hurwitz, Jon, and Mark Peffley. 1987. "How Are Foreign Policy Attitudes Structured? A Hierarchical Model." American Political Science Review 81 (4): 1099-1100. DOI: https://doi.org/10.2307/1962580

Hurwitz, Jon, Mark Peffley, and Mitchell Seligson. 1993. "Foreign Policy Belief Systems in Comparative Perspective: The United States and Costa Rica." International Studies Quarterly 37 (3): 245-270. DOI: https://doi.org/10.2307/2600808

Lafer, Celso. 2000. "Brazilian International Identity and Foreign Policy: Past, Present, and Future." Daedalus129 (2): 207-238. 
Lafer, Celso. 2001. A identidade internacional do Brasil e a política externa brasileira: Passado, presente e futuro. São Paulo: Perspectiva.

Lima, Maria Regina Soares. 2005. "Aspiração internacional e política externa." RBCE (82): 4-19.

Lopes, Dawisson. 2010. "Da razão de Estado ao republicanismo mitigado: A plausibilidade de uma política externa democraticamente orientada no Brasil contemporâneo." PhD diss., Universidade do Estado do Rio de Janeiro, Rio de Janeiro.

Loureiro, Felipe, Feliciano Guimarães, and Adriana Schor. 2015. "Public Opinion and Foreign Policy in João Goulart's Brazil (1961-1964): Coherence between National and Foreign Policy Perceptions?" Revista Brasileira de Política Internacional 58 (2): 98-118. DOI: https://doi.org/10.1590/0034-7329201500206

Lustig, Carola, and Tomás Olego. 2016. "Public Opinion and Framing Effects of Argentine Foreign Policy toward Brazil: Evidence from a Survey Experiment in Urban Centers in Argentina." Contexto Internacional 38 (1): 241-275. DOI: https://doi.org/10.1590/S0102-8529.2016380100007

Maggiotto, Michael, and Eugene R. Wittkopf. 1981. "American Public Attitudes toward Foreign Policy." International Studies Quarterly 25 (4): 601-631. DOI: https://doi.org/10.2307/2600514

Malamud, Andrés. 2011. "A Leader without Followers? The Growing Divergence between the Regional and Global Performance of Brazilian Foreign Policy." Latin American Politics and Society 53 (3): 1-24. DOI: https://doi.org/10.1111/j.1548-2456.2011.00123.x

Moura, Gérson. 1985. "As razões do alinhamento: A política externa brasileira no pós-guerra, 1946-1950." Revista Brasileira de Política Internacional, No. 28: 37-50.

Mourón, Fernando, Francisco Urdinez, and Janina Onuki. 2016. "Framing Effects on Foreign Policy: Experimental Evidence from Emerging Countries and the Argentine-Brazilian Rivalry." Opinião Pública 22: 195-218. DOI: https://doi.org/10.1590/1807-01912016221195

Onuki, Janina, Fernando Mourón, and Francisco Urdinez. 2016. "Latin American Perceptions in Comparative Perspective: Regional Identity and Contested Leadership." Contexto Internacional 38: 45-69. DOI: https://doi.org/10.1590/S0102-8529.2016380100012

Page, Benjamin, and Robert Shapiro. 1982. "Changes in Americans' Policy Preferences, 1935-1979." Public Opinion Quarterly 46 (1): 24-42. DOI: https://doi.org/10.1086/268697

Page, Benjamin, and Robert Shapiro. 1992. The Rational Public: Fifty Years of Trends in Americans' Foreign Policy Preferences. Chicago: University of Chicago Press. DOI: https://doi.org/10.7208/ chicago/9780226644806.001.0001

Peffley, Mark, and Jon Hurwitz. 1992. "International Events and Foreign Policy Beliefs: Public Response to Changing Soviet-US Relations." American Journal of Political Science 36 (2): 431-461. DOI: https:// doi.org/10.2307/2111485

Popkin, Samuel. 1993. The Reasoning Voter: Communication and Persuasion in Presidential Campaigns. Chicago: University of Chicago Press.

Reynolds, Evangeline; Amâncio Oliveira, Janina Onuki, and Matthew Winters. 2017. "Attitudes toward Consent-Based and Non-Consent-Based International Law in a Regional Power Context." International Interactions 44 (4): 661-680. DOI: https://doi.org/10.1080/03050629.2018.1408012

Ricupero, Rubens. 2000. Rio Branco: O Brasil no mundo. Rio de Janeiro: Contraponto.

Ricupero, Rubens. 2017a. A diplomacia na construção do Brasil, 1750-2016. Rio de Janeiro: Versátil Editores.

Ricupero, Rubens. 2017b. "The Foreign Policy of the First Republic (1889-1930)." In Brazilian Diplomatic Thought, edited by José Vicente Pimentel, 3:349-374. Brasília: FUNAG.

Schiavon, Jorge. 2010. "La migración México-Estados Unidos: Entre intereses, simulaciones y opciones reales de política." In Perspectivas migratorias: Un análisis interdisciplinario de la migración internacional, edited by Jorge Durand and Jorge A. Schiavon, 221-251. Mexico City: Centro de Investigación y Docencia Económicas.

Schiavon, Jorge, and Rafael Flores. 2010. "La incidencia de la opinión pública en la política exterior de México: Teoría y realidad." Working Paper No. 197, Centro de Investigación y Docencia Económicas, Mexico City.

Shapiro, Robert, and Benjamin Page. 1988. "Foreign Policy and the Rational Public." Journal of Conflict Resolution 32: 211-247. DOI: https://doi.org/10.1177/0022002788032002001

Sniderman, Paul, Richard Brody, and Philip Tetlock. 1991. Reasoning and Choice: Explorations in Political Psychology. Cambridge: Cambridge University Press. DOI: https://doi.org/10.1017/CBO9780511720 468

Souza, Amaury. 2008. O Brasil na região e no mundo: Percepções da comunidade brasileira de política externa. Rio de Janeiro: Centro Brasileiro de Relações Internacionais. 
Vigevani, Tullo, and Gabriel Cepaluni. 2007. "Lula's Foreign Policy and the Quest for Autonomy through Diversification." Third World Quarterly 28 (7): 1309-1326. DOI: https://doi.org/10.1080/ 01436590701547095

Vigevani, Tullo, and Haroldo Ramanzini Júnior. 2010. "Pensamento brasileiro e integração regional." Contexto Internacional 38 (2): 437-487. DOI: https://doi.org/10.1590/S0102-85292010000200006

Wittkopf, Eugene R. 1990. Faces of Internationalism: Public Opinion and American Foreign Policy. Durham, NC: Duke University Press.

How to cite this article: Almeida, Maria Hermínia Tavares de, Ivan Filipe Fernandes, and Feliciano de Sá Guimarães. 2021. Structuring Public Opinion on Foreign Policy Issues: The Case of Brazil. Latin American Research Review 56(3), pp. 557-574. DOl: https://doi.org/10.25222/larr.876

\section{Submitted: 15 February $2019 \quad$ Accepted: 09 August $2020 \quad$ Published: 07 September 2021}

Copyright: (c) 2021 The Author(s). This is an open-access article distributed under the terms of the Creative Commons Attribution 4.0 International License (CC-BY 4.0), which permits unrestricted use, distribution, and reproduction in any medium, provided the original author and source are credited. See http://creativecommons.org/ licenses/by/4.0/. 